\title{
Research Paper \\ The Effect of Social Networking Tools on the SMEs Domain: an empirical study in the Nineveh Governorate-Iraq
}

Journal of

\section{TANMIYAT AL- RAFIDAIN}

\section{(TANRA)}

A scientific, quarterly, international, open access, and peer-reviewed journal

Vol. 39, No. 126

June, 2020

(C) University of Mosul |

College of Administration and

Economics, Mosul, Iraq.

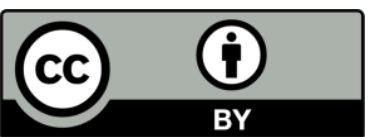

TANRA retain the copyright of published articles, which is released under a "Creative Commons Attribution License for CC-BY-4.0" enabling the unrestricted use, distribution, and reproduction of an article in any medium, provided that the original work is properly cited.

Citation: Zaker, Rabee A. (2020). "The Effect of Social Networking Tools on the SMEs Domain: an empirical study in the Nineveh Governorate-Iraqf" TANMIYAT AL-RAFIDAIN, 39 (126), 9- 20, https://doi.org/10.33899/tanra.20 20.165649

P-ISSN: 1609-591X e-ISSN: 2664-276X tanmiyat.mosuljournals.com
Rabee A. Zaker ${ }^{1}$

${ }^{1}$ Faculty of Administration and Economics, University of AL-Hamdaniya

Corresponding author: Rabee A. Zaker, Faculty of Administration and Economics, University of AL-Hamdaniya , rabeeali2012@gmail.com

DOI: https://doi.org/10.33899/tanra.2020.165649

Article History: Received: / /2020; Revised: 30/11/2019; Accepted: 31/12/2019; Published: 1/3/2020.

\begin{abstract}
The main goal of this work is to reveal the effect of Social Networking Tools (SNT) on the Small and Medium Enterprises (SMEs) domain. The work has been done in the food field in Nineveh region-Iraq. The author has selected Facebook application as a tool of social network, this represents the independent variable. Whereas the dependent variables consist of customer retention and customer involvement. Standard questionnaire has been prepared in order to collect the data from the samples. Collected data have been analyzed using SPSS-20 software package. It was founded that the use of Facebook as a tool of SNT will rapidly increase the promotion and motivate consumers in order to engage with the respected industry. The results also illustrate that there is a relation and influence between SNT usage and both of; customer retention and customer involvement.
\end{abstract}

\section{Keywords}

Social Networking, Social Networking Tools, Costumer Involvement and Retention, Small and Medium Enterprises. 
تأثير أدوات الشبكات الاجتماعية على مجال المشاريع المتوسطة والصغيرة: دراسة تجريبية في محافظة نينوى-العراق

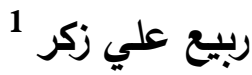

1 كلية الإدارة والاقتصاد، جامعة الحمدانية

المؤلف المراسل: ربيع علي زكر، كلية الإدارة والاقتصاد، جامعة الحمدانية، نينوى، العراق، rabeeali2012@gmail.com

DOI: https://doi.org/10.33899/tanra.2020.165649

تاريخ المقالة: الاستلام: 2/8 /2020؛ التعديل والتتقيح: /2020/6؛ القبول: 2020/4/8؛

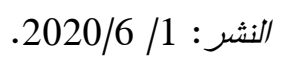

إن الهذف الرئبس من هذا العمل هو الكثف عن تأثبر أدوات الثبكات الاجتماعية (SNT)

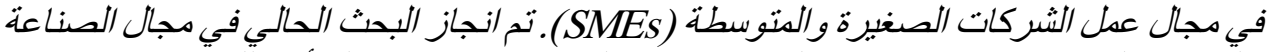

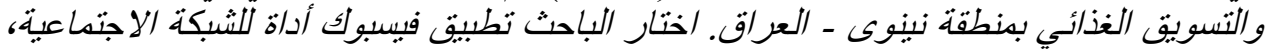

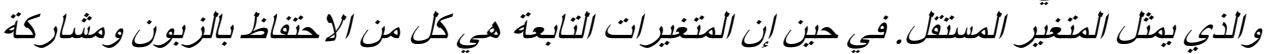

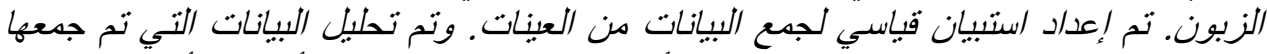

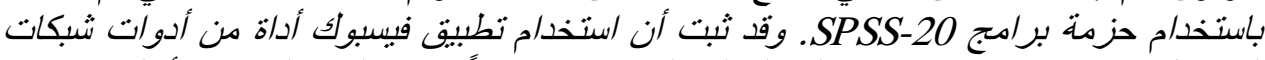

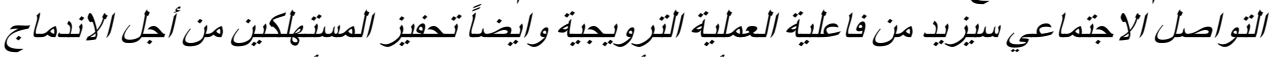

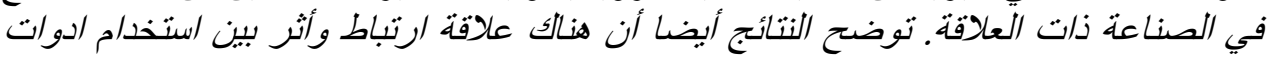
شبكات التواصل الاجتماعي وكلا من الاحتفاظ بالزبون ومشان الناركة الزبون.

\section{الكلمات الرئيسة}

الثبكات الاجتماعية ، أدوات الثبكات الاجتماعية ، مشاركة والاحتفاظ بالزبائن ، المشاريع الصغيرة

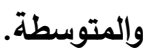

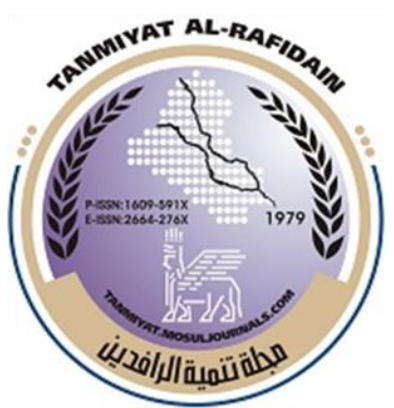

تنسية الرافدين

(TANRA) دولية، مفتوحة الوصول، محكمة.

$$
\text { حزيران المجلد (39)، العدد (126)، }
$$

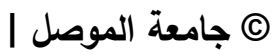
كلية الإدارة والاقتصاد، الموصل، العراق.

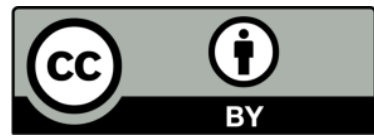

تحتفظ (TANRA) بحقوق الطبع والنشر للمقالات المنشورة، والتي يتم إصدارها بموجب ترخيص 」 (Creative Commons Attribution) (CC-BY-4.0) الذي يتيح الاستخدام، والتوزيع،

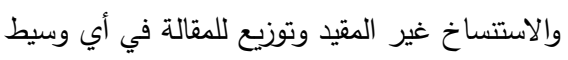
نقل، بشرط اقتباس العمل الأصلي بشكل صحيح. الاقتباس: زكر ، ربيع علي (2020). "

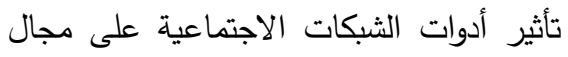
المشاريع المتوسطة والصغيرة: دراسة تجريبية في محافظة نينوى-العراق ". تنمبية الرافدين، ولين، ، 20 -9 39

https://doi.org/10.33899/tanra.20 20.165649

P-ISSN: 1609-591X

e-ISSN: 2664-276X

tanmiyat.mosuljournals.com 


\section{Introduction:}

These days, utilization of "Information and Communication Technologies" ICT has made a big change in numerous facets of the humane lives and its effect is increasing in diverse sectors. This has been supported by the emerging of second generation of web-based communities like "blogs, wikis, and social networking tools" which is targeting the beginning of: collaboration, creativity, and sharing amongst customers instead of just sending and/or receiving emails and retrieve information. Depending on this, consumers will become more empowered throughout having data on the "Web 2.0.", furthermore, customer relationships with the company that serves them will be improved (Anshari and Almunawar, 2012). The relationship with the consumer is more and more influenced by a consumer community existing on social networks. As a result, the method of association with the consumer is made has been changed throughout history course (Ngai, et al., 2015). The expansion of these days' technologies has largely enabled clients to quickly and with fewer difficulties collect information about the supply of diverse goods and services. It will also make it easy for customers to find out the best with highest quality providers. The customer is capable to select and to make a decision about who will provide the best offer (Habul et al., 2012). This paper is keen to present a conceptual framework for which Nineveh's SMEs adoption the tools of social networking in order to involvement consumers within its marketing activities and towards customer's retention.

\section{Literature Survey}

In this section, author tried to demonstrate some of the related previous work. Cornejo in 2017, introduced his work under title "Social media impact on consumers food choice". He examined the customers' decisions before visiting any restaurant. This has been done through determination the type of food choice "behavior" of the customer. The main conclusion of the work was the possibility of food testing from consumers depending on what is sharing from food industry firms by social media tools. Ioanid et al., (2018) studied the impact of social networks on SMEs innovation potential. This study highlighted the involving other parties like consumers and suppliers into innovation process through using social network. Perumal et al.(2017) presented their study about the use of "social media in food and beverages industry". The work examines the elements influencing utilization of social media being a marketing media. They highlighted that 'brand awareness' and 'customer acquisition and retention' have strong relationship with using of social media, whereas 'information platform' and 'feedback' have negative relationship with the using of social media. Öztamur and Karakadilar (2014) accomplished a work about the role of social media as a new marketing strategy tool in small and medium enterprises domain. The study highlighted this relation in the firm performance perspective. Facebook and Twitter were the social networking tools which have been used as a measurement. It was doing a comparison between four Turkish and American firms. The findings refer that the Turkish firms are quite better in terms of applying the required strategies and factors when compared to

TANMIYAT AL-RAFIDAIN (P-ISSN: 1609-591X; E-ISSN: 2664-276X) تنمية الرافدين 
American firm's social media use. Another study about the adoption and use of social media in SMEs, has been conducted and investigated by Meske and Stieglitz (2013). This effort related to measure the benefits from the using of social media application by German small and medium entrepreneurs. Target respondents were 190 decision - makers in the selected SMEs. The work, found that these enterprises are using social media for the enhancement and supporting of the internal collaboration between employees, beside the improvement of the knowledge management. Alshamaila (2018) presented his study about the usage of social network site in the context of small and medium sized businesses in Jordan. The motivations and barriers implications of using SNSs have been investigated. Also, the determination of decision making in selected area has been tested in order to highlight the implication of SNS in the small and medium sized businesses. The finding of the study referred to the three motivating factors as a result of using SNS; interactivity, community demand, and relative advantage. Whereas the barriers adoption was; negative comments and reviews, firm readiness, low awareness, and top management trust. A very interested paper in this respect, has been given by Annisa and Mahendrawathi (2019) the work was very interested due to the model theory that has been introduced. The main goal of the work was to provide a new view of the applying information technology in the SMEs. As such it was an attempt to fill the gap for how the SMEs can reap from the use of social media application. Authors have dependent on the "Honeycomb Model" to take a benefit from recruit social media to support functional levels of the SMEs. Furthermore, researchers refer that social media can support business process performance level in the said arena. Depending on the previous contribution in the literature survey, the current study is agreeing with Annisa and Mahendrawathi (2019). Social networking tools would be a great technique to be engaged with daily process level of SMEs. In more detail, the managerial implication of the current work is related to reducing advertising costs beside the information transmission between the company and its employees. This will lead to the consumer retention as well as consumer involvement with functional process as feedback source about firms' downsides services or its product's response to the client's needs.

\section{Literature Review}

Recently, in most countries, Small and medium-sized enterprises (SMEs) are dominate the commercial and industrial infrastructure. SMEs are imperative to financial development in terms of pushing the improvement wheel and making unused employments, particularly highgrowth ones decreasing recessionary pressures and maintaining survival. In developing countries SMEs segment become one of the latest key issues since this sector may sustain the livelihood of many people directly or indirectly (Al Baghlani, 2018). Johansson and Corvera (2012) emphasizes that the key advantages for applying SNT in SMEs daily activities are cost savings and getting closer to the customer. Furthermore, SNT can provide SMEs sector a vast opportunity in order to raise their presence and enlarge their sales (Rugova and Prenaj, 2016).

TANMIYAT AL-RAFIDAIN (P-ISSN: 1609-591X; E-ISSN: 2664-276X) تنمية الرافدين 


\subsection{Social Networking Tools}

Social Networking Tools (SNT) represents online social relations focuses on connection which empower costumers in order to construct online profiling toward digital media. Generally, the prevalent types of SNT services could be expressed from mailing list community, e-mail service, and instant messenger. Newly, SNT which is based on "Web 2.0 technology" like, Twitter, LinkedIn, Myspace, Facebook, Friendster, etc., have speedily facilitate ease of networking social, ease of participation, and peer-to-peer collaboration (Anshari and Almunawar, 2012). Furthermore, SNT represents a very good way towards build and control online community which brings people together. In resent information era, SNT allows individual to be connected and manage existing relationship even with the companies (Ramsaran-Fowdar, 20013). SNT are exchangeable used as Social networking sites or Social Media. Its applications empower users to associate by making individual data profiles, allowing friends to access those profiles, and enabling them to send and receive emails messages between each other (Kaplan and Haenlein, 2010). SNT empower all people having internet to entrance any pages created by organizations and communicate about personal things (Palmer and Lewis, 2009). The quick development of social commerce is primarily due to the fast dissemination of SNT like Facebook and Twitter. This will change conventional firm processes by giving better client shopping understanding such as "access to friends purchasing experiences, real-time sharing of purchase actions with friends before final purchase decisions" (Zhou et al., 2011). This will help organizational staff to find out costumer's thoughts about enterprises products, services, and brands. Furthermore, a positive experience of the organization's output will be given to the Internet users (Srinivasan et al., 2011).

\subsection{Facebook Application}

First of all, the author has preferred to dependent on Facebook as a tool of $\mathrm{SN}$. This, because this tool is the most popular among the social media users around the country. The new phenomena related to the communication between individuals has been widely separated in 2004. A young student called Mark Zuckerberg and his collogues in Cambridge University, produced a new method of the interaction in order to allow the students to connect together. This technique named "Facebook". In the beginning the range of the application was only for the use in the Universities. After that, business world has paid great attention to the possibility of benefiting from the technology. The Creation of profile page including personal information, was the crucial condition for personal interactive to be done (Brügger, 2015). It has a great capacity in order create personal relations and direct individuals to enter an unfamiliar social environment. Facebook application, allows people to express themselves, seek information, and interact together (Ainin et al., 2015). Organizations can easily take an advantage from creating their own profile on Facebook. This step will help to disseminate data and information related to the firm's products and services. This action will be a very good way in order to transfer from the target of build a relationship with the clients to the target of reaching them

TANMIYAT AL-RAFIDAIN (P-ISSN: 1609-591X; E-ISSN: 2664-276X) تنمية الرافدين 
directly. Furthermore, such community is relevant to the marketers, as they will be able to identify consumers Desires and needs. This will help them to formulate marketing strategies besides creating market segmentation (Ramsaran-Fowdar, 2013).

\subsection{Customer Involvement}

This term implies involving the client in activities related to development and improvement of new goods including; advertise assessment, supply chain, market evaluation, and technical meetings. Customer involvement represents a platform in order to get better understanding of the future market demands (Ghafari et al., 2011). It represents the main key character of any service, besides gaining more competitive advantage. Customer involvement emphasizes a closeup relationship between organizations and clients. As a result, the enterprises will have benefits from customer participation throughout improvements of firm performance (Anning-Dorson, 2018). Moreover, consumes could be involved with the organization business activities through firms' efforts towards building and controlling online community which brings clients around products and services. In today's information age, customer involvement lets individual to be connected and managed depending on the current relationship even with the companies (Ramsaran-Fowdar, 20013).

\subsection{Customer Retention}

It has been referred that the customer satisfaction represents a main key of the customer retention. Satisfaction is a priority of the consumer decision for continue or terminate a business relationship. Social networks can play a high role towards direct accountability around customer groups and addressing the particular problems of customer's discontent, thus increasing the retention rate. At the same time, Social networks can empower organizations efficiently and effectively towards retaining customers (Anning - Dorson, 2018). In the same context, organizational social networks tools could be a helpful way in the enhancement of consumer self- service and enables them which let the organizations to decrease costs through managing and increasing number of customer's transactions effectively (Anshari and Almunawar, 2012). There is no doubt that the process of consumer retention has a direct and great effect on the making profitability. As well as, customer retention could be more difficult and more expensive comparing with get new client. The difficulties reason is due to the high competition towards those customers. The reality is that the Customer Relationship Management (CRM) represents the main way to help companies in leveraging the information and experience in retention and development of a profitable consumer portfolio (Yilmaz and Ferman, 2017).

\section{Methodology}

SMEs represents a main component of the resent economy and spite of the SMEs marketing approaches might be differ from big organizations, SMEs represent more than $80 \%$ of the total number of establishments in the processed

TANMIYAT AL-RAFIDAIN (P-ISSN: 1609-591X; E-ISSN: 2664-276X) تنمية الرافدين 
food section. In Iraq, the number of employs for small enterprises is between 1-9 employs and for medium enterprises it's between 10-29 employs. The focuses of this work have been done in food industries. This work included members of Business to Costumer (B2C) SMEs. Actually, as we know the SMEs spending ability on advertising is less than big organizations. This vision could be the main reason to adopt SNT in SMEs domain. Data were collected from the selected SMEs members in Nineveh Governorate-Iraq. Questioners have been randomly distributed among samples. The author tested the adoption of a specific social networking tool, the "Facebook" tool. The samples were asked to explain how their enterprises were engaging with the tool using five-point Likert scale. Target respondents were the employees of the selected SMEs. 69 individual staffs taken randomly. As 69 questionnaires distributed, 56 of them have been collected. 13 of them have been excluded due to missing some data in the questionnaire. The questionnaire has been developed through apply five-point Likert scale in order to measure respondents' ratings. The rating scale included five levels, 5 is "highest" and 1 is the "lowest" ratings. While 2, 3, and 4 are "I don't agree", "Neutral", and "Agree". The questionnaire consists of 15 items about the study; Social Networking Tools (the independent variable) to the Customer Involvement and Customer Retention (the depended variable). It included: (A) 8 items relating to Social Networking; (B) 7 items relating to the Customer Involvement and Customer Retention. All the questions of the questionnaire have been formulated by the author adapted from Anshari and Almunawar (2012), Zhou et al. (2013), Srinivasan et al. (2011), Chan et al., 2010 and Ghafari et al., 2011.

The methodology of this work could be clarified throughout the coming main features:

\subsection{Problem determination}

As the best knowledge of the author there are on works have been studied (locally) the exact idea of the present study. This has motived the author to take a first step in this regard. As the same time this could be considered as the originality of the work. The work problem can be recognized throughout the two main questions:

(a) Is there a "relationship" between Social Networking Tools with both; Customer Involvement and Customer retention in the selected SMEs in Nineveh Governorate?

(b) Does Social Networking Tools have an influence on the Customer Involvement and Customer retention in the selected SMEs in Nineveh Governorate?

\subsection{Hypothesis}

The questions posed in the research problem could be answered throughout the next hypotheses:

H1: There is a "significant relationship" between Social Networking Tools with both; Customer Involvement and Customer retention in the selected SMEs in Nineveh Governorate.

TANMIYAT AL-RAFIDAIN (P-ISSN: 1609-591X; E-ISSN: 2664-276X) تنمية الرافدين 
H2: There is a "significant influence" of Social Networking Tools on the Customer Involvement and Customer retention in the selected SMEs in Nineveh Governorate.

\subsection{Purposes}

This research aims to realize some objectives, such as:

1. To discover "the relationships" between Social Networking Tools with both; Customer Involvement and Customer retention in the selected SMEs in Nineveh Governorate.

2. To discover "the influence" of Social Networking Tools on the Customer Involvement and Customer retention in the selected SMEs in Nineveh Governorate.

\section{Data Analyses and Results Dissections}

5.1 Analyzing Sample Characteristics

Table-1-presenting the characteristics of the respondents targeted in this work:

\begin{tabular}{|c|c|c|c|c|c|c|c|}
\hline \multicolumn{8}{|c|}{ Table (1) : Demography characteristics } \\
\hline \multicolumn{8}{|c|}{ Gender } \\
\hline \multicolumn{4}{|c|}{ Male } & \multicolumn{4}{|c|}{ Female } \\
\hline \multicolumn{2}{|c|}{ Frequency } & \multicolumn{2}{|l|}{$\%$} & \multicolumn{2}{|c|}{ Frequency } & \multicolumn{2}{|l|}{$\%$} \\
\hline \multicolumn{2}{|c|}{38} & \multicolumn{2}{|c|}{67.86} & \multicolumn{2}{|c|}{18} & \multicolumn{2}{|c|}{32.14} \\
\hline \multicolumn{8}{|c|}{ Age } \\
\hline \multicolumn{2}{|c|}{ Below 25} & \multicolumn{2}{|c|}{$25-35$} & \multicolumn{2}{|c|}{$35-45$} & \multicolumn{2}{|c|}{ Above 45} \\
\hline Frequency & $\%$ & Frequency & $\%$ & Frequency & $\%$ & Frequency & $\%$ \\
\hline 12 & 21.42 & 24 & 42.86 & 12 & 21.42 & 8 & 14.29 \\
\hline \multicolumn{8}{|c|}{ Education } \\
\hline \multicolumn{2}{|c|}{ Graduate } & \multicolumn{2}{|c|}{ diploma certificate } & \multicolumn{2}{|c|}{$\begin{array}{l}\text { High School- } \\
\text { Graduate }\end{array}$} & \multicolumn{2}{|c|}{ other qualification } \\
\hline Frequency & $\%$ & Frequency & $\%$ & Frequency & $\%$ & Frequency & $\%$ \\
\hline 66.07 & 37 & 5.36 & 3 & 19.64 & 11 & 8.93 & 5 \\
\hline \multicolumn{8}{|c|}{ Period of Establishment } \\
\hline \multicolumn{2}{|c|}{ 3-5 years } & \multicolumn{2}{|c|}{ 6-10 years } & \multicolumn{4}{|c|}{11 years and above } \\
\hline Frequency & $\%$ & Frequency & $\%$ & & requenc & & $\%$ \\
\hline 27 & 48.21 & 18 & 32.14 & & 11 & & 19.64 \\
\hline
\end{tabular}

\section{- Gender}

Out of 56 distributed questionnaires, it has been observed that "males" were $67.86 \%(n=38)$ while the "females" were $32.14 \%(n=18)$. We conclude from this that the males formed the largest proportion by $67.86 \%$.

- Age

Out of 56 respondents, $14.29 \%(n=8)$ are above 45 years, $42.86 \%(n=24)$ fall between 25-35 years, $21.43 \%(n=12)$ fall below 25 years and $21.42 \%(n=12)$ fall between $35-45$. As a result, it has been observed that the majority of respondents belong to age between 25-35. This means the most enterprises are managed by young people.

TANMIYAT AL-RAFIDAIN (P-ISSN: 1609-591X; E-ISSN: 2664-276X) تنمية الرافدين 


\section{- Education}

Out of 56 workers, $66.07 \%(n=37)$ were "graduate", 5.36\% $(n=3)$ were having diploma certificate, $19.64 \%(n=11)$ were High School-Graduate, $8.93 \%(n=5)$ were having other qualification. This means that the majority of the respondents are having high qualification which is helping their enterprises to take benefits from different internet applications.

\section{- Period of Establishment}

Regarding the period of starting the enterprise, the results has shown the Following time categories respectively; $48.21 \%(\mathrm{n}=27)$ fall between $(3-5$ years), 32.14\% $(n=18)$ fall between $(6-10$ years $)$, and $19.64 \%(n=11)$ fall between (11 years and above).

\subsection{Reliability}

Cronbach's Alpha has been used in order to test the "internal consistency" as it's shown in the below table.

Table (2): Reliability Statistics

\begin{tabular}{|c|c|}
\hline \multirow{2}{*}{ Reliability } & Cronbach's Alpha \\
\cline { 2 - 2 } & 0.80 \\
\hline
\end{tabular}

Source: SPSS Results

The "alpha coefficient" calculated in the table 1 , was 0.80 . This indicate that the items have comparatively high internal consistency. Therefore, it would be considered this rate is convenient for the study done.

\subsection{Hypotheses Testing Hypothesis 1:}

Table (3): The correlation between the independent variable "Social Networking Tools" and dependent variables: Customer Acquisition and Customer retention

\begin{tabular}{l|c|c|}
\hline Depended variables & $\begin{array}{c}\text { Customer } \\
\text { Involvement }\end{array}$ & Customer retention \\
\hline Independents variable & $.427^{* *}$ & $.356^{* *}$ \\
\hline$*$ Cocial Networking Tools & \\
$\quad$ Source: SPSS Results.
\end{tabular}

In order to verify the main hypothesis one, author implemented correlation test. Main hypothesis one states that "there is a significant relationship between Social Networking Tools and both; Customer Involvement and Customer retention in the selected SMEs in Nineveh Governorate". The table (2) shows that there is a correlation between Social Networking Tools and both; Customer Involvement and Customer retention, as the value of $\mathrm{r}=.42$ for the customer involvement which is significant at 0.01 level. As such, the value of $r=.35$ for the customer retention

TANMIYAT AL-RAFIDAIN (P-ISSN: 1609-591X; E-ISSN: 2664-276X) تنمية الرافدين 
which is significant at 0.01 level. According to the correlation, first hypothesis has been accepted.

Hypothesis 2:

Table 4

Model Summary of "Regression analysis" between Social Networking Tools with Customer Involvement and Customer retention

\begin{tabular}{|c|c|c|c|c|c|c|}
\hline \multirow{2}{*}{ Dependent variables } & \multicolumn{6}{|c|}{ Social Networking Tools } \\
\hline & \multirow{2}{*}{$\mathbf{R}^{2}$} & \multirow{2}{*}{ D.F } & \multicolumn{2}{|c|}{$\mathbf{F}$} & \multirow{2}{*}{$\mathbf{0 \beta}$} & \multirow[b]{2}{*}{$\boldsymbol{\beta}$} \\
\hline \multirow[b]{2}{*}{ Customer Involvement } & & & Founded & Sig & & \\
\hline & .182 & \multirow[t]{2}{*}{2} & 12.017 & .001 & 2.556 & 3.467 \\
\hline Customer Retention & .127 & & 7.827 & .000 & .265 & 2.798 \\
\hline
\end{tabular}

** Correlation is "significant" at 0.01 level $\mathrm{N}=56$

Source: SPSS Results.

The results denoting that Social Networking Tools being affect Customer Involvement and Customer retention which is clarified in table (3), it has been detected that the coefficient $\mathrm{R}^{2}$ pointed that the explain difference proportion in Customer Involvement due to the "influence" of Social Networking Tools for Customer Involvement is $18.2 \%, \mathrm{~F}(1,54)=12.01, \mathrm{p}<0.01$, beta is 2.55 beside $\mathrm{t}$ value of 3.46, this is significant at 0.01 level. Also it has been detected that the specifying coefficient $\mathrm{R}^{2}$ pointed that the explain difference proportion in Customer retention due to the "influence" of Social Networking Tools for Customer Involvement is $12.7 \%, F(1,54)=7.82, p<0.01$, beta is .26 beside $t$ value of 2.79 this is significant at 0.01 level. According to the results second hypothesis has been accepted.

\section{Conclusions:}

In current environment, consumers can organize their associations with companies and achieve power in order to influence other clients in their social network. In the light of the growing dissemination of social networking tools within business environment, it is essential that the organization take in mind the benefits and obstacles associated with their adoption and use. Therefore, it is vital for SMEs to recognize social networking tools such as Facebook, You Tube, Twitter, etc. and trying to apply and use these tools for business growing. This work attempted to highlight the social networking tools that are using and applying from the selected Small and Medium Enterprises in Nineveh Governorate-Iraqi. In general, the contribution of Small and Medium Enterprises in the Iraqi economy remains a neglected area. However basic governmental support to SMEs has been lately started. Based on this work, results have indicated that there is a significance relation between social networking tools and customer involvement, customer retention respectively.

Research limitations and further works:

This study focused on the SMEs working in the field of food and investigated the relation between adopting of Facebook as a tool of social network

TANMIYAT AL-RAFIDAIN (P-ISSN: 1609-591X; E-ISSN: 2664-276X) تنمية الرافدين 
and customer retention beside customer involvement. The main limitation of the work is the small sample under test beside the geographical location only in Nineveh, Iraq. So, the generalization of the study will be limited. It's better for the future works to be more general in different provinces. Furthermore, the study could be applying in another industries. Also, the researchers my investigate other tools of SNT like YouTube, Snapchat etc., in order to study the relationship amongst them. Future works could be advised to discover and study the applying of SNT in order to improve and engage with the strategic implementation in SMEs and in other sectors.

\section{References}

Anshari, M. A., and Almunawar, M. N. 2012, Framework of Social Customer Relationship Management in E-Health Services, Journal of e-Health Management, DOI: $10.5171 / 2012.766268$.

Ngai, E., Moon, K., Lam, S., Chin, E. and Tao, S. (2015). Social media models, technologies, and applications: An academic review and case study. Industrial Management \& Data Systems, 115(5), 769-802 . doi.org/10.1108/IMDS-03-20150075.

Al Baghlani, A. L. K. (2018). An Investigation into Strategies Used by Iraqi SMEs To Survive in The Hostile Environment: The Case of Al-Khaleej Company. Academy of Entrepreneurship Journal, 24(1).

Palmer, A., \& Koenig-Lewis, N. (2009). An experiential, social network-based approach to direct marketing. Direct Marketing: An International Journal, 3(3), 162176.doi.org/10.1108/17505930910985116

Zhou, L., Zhang, P., \& Zimmermann, H. D. (2013). Social commerce research: An integrated view. Electronic commerce research and applications, 12(2), 61-68. doi.org/10.1016/j.elerap.2013.02.003

Culnan, M. J., McHugh, P. J., \& Zubillaga, J. I. (2010). How large US companies can use Twitter and other social media to gain business value. MIS Quarterly Executive, 9(4), 243-259.

Srinivasan, R., Bajaj, R., \& Bhanot, S. (2016). Impact of social media marketing strategies used by micro small and medium enterprises (MSMEs) on Customer acquisition and retention. IOSR Journal of Business and Management, 18(1), 91-101.

Kaplan, A. M., \& Haenlein, M. (2010). Users of the world, unite! The challenges and opportunities of Social Media. Business horizons, 53(1), 59-68.

Habul, A., Pilav-Velić, A., \& Kremić, E. (2012). Customer Relationship Management and Business Intelligence. Advances in Customer Relationship Management. Rijeka: InTech Europe, 13-30.

Rugova, B., \& Prenaj, B. (2016). Social media as marketing tool for SMEs: opportunities and challenges. Academic Journal of Business, 2(3), 85-97.

Ghafari, P., Karjalian, R., \& Mashayekhnia, A. (2011). Studying the relationship between different dimensions of CRM and innovation capabilities in Melli bank of Iran. World academy of science, engineering and technology, 60(12), 906-10.

Anning-Dorson, T. (2018). Customer involvement capability and service firm performance: The mediating role of innovation. Journal of Business Research, 86, 269-280.

TANMIYAT AL-RAFIDAIN (P-ISSN: 1609-591X; E-ISSN: 2664-276X) تنمية الرافدين 


\section{.}

Zaker

Cornejo, A. D. O. (2017). Social media impact on consumer's food choice. Master Thesis, Universität Kassel, Germany.

Ioanid, A., Deselnicu, D. C., \& Militaru, G. (2018). The impact of social networks on SMEs' innovation potential. Procedia Manufacturing, 22, 936-941.

Perumal, I., Krisnan, U. D., \& Halim, N. S. B. A. (2017). Social media in food and beverages industry: case of Klang Valley, Malaysia. International Journal of Business and Management, 12(6), 121-127.

Öztamur, D., \& Karakadılar, İ. S. (2014). Exploring the role of social media for SMEs: as a new marketing strategy tool for the firm performance perspective. ProcediaSocial and behavioral sciences, 150, 511-520. doi: org/10.1016/j.sbspro.2014.09.067.

Meske, C., \& Stieglitz, S. (2013, June). Adoption and use of social media in small and medium-sized enterprises. In working conference on practice-driven research on enterprise transformation (pp. 61-75). Springer, Berlin, Heidelberg.

Brügger, N. (2015). A brief history of Facebook as a media text: The development of an empty structure. First Monday, 20(5).,doi: 10.5210/fm.v20i5.5423.

Ainin, S., Naqshbandi, M. M., Moghavvemi, S., \& Jaafar, N. I. (2015). Facebook usage, socialization and academic performance. Computers \& Education, 83, 64-73.

Ramsaran-Fowdar, R. R., \& Fowdar, S. (2013). The implications of Facebook marketing for organizations. Contemporary Management Research, 9 (1). doi:10.7903/cmr.9710.

Yilmaz, K. O., \& Ferman, M. (2017). An Applied Study on The Customer Retention Dynamics of Organized Ready-To-Wear Textiles Retailers in Real and Virtual Markets in Turkey. Journal of Management Marketing and Logistics, 4(4), 366383. 